\title{
Chosen Model of Privatization of Socially Owned Enterprise in Kosovo Over Kosovo Trust
} Agency

\author{
Dr. Bajram Fejzullahu
}

Republic of Kosovo, bajram_fejzullahu@hotmail.com

\begin{abstract}
Unlike in the countries of Central and South-East Europe, where the transformation of property and political transition were smooth and peaceful, in the countries of former Yugoslavia (except Montenegro and Macedonia) these processes were accompanied by war; the effects are present even nowadays. After 1999, it was Kosovo's turn to be part of these changes. Normally, in these processes, the political transition occurs prior to the transformation of property. This was not the case in Kosovo, where the order was reversed. It cannot be said that the privatisation method chosen by UNMIK was not the best. As of now, this method has failed to fulfil its duties of economic recovery and solve the unemployment problem. UNMIK has chosen the method of transforming the social property of Kosovo as a set up for the total transition of the political system, which later on would be one of the main elements and will serve to proclaim independence of Republic of Kosovo. It will remain an unanswered question whether the method that used is actually better, whether it is more productive economically, or not. As Kosovo's case for many things is sui generis, and as far as the process of privatisation of the social property is concerned, it is a process which tried to adjust to the existing circumstances in Kosovo, circumstances which were earlier unknown in the other countries.
\end{abstract}

Keywords: Kosovo, privatization, process, agency, models, property, transformation

\section{Chosen model of privatization of Socially Owned Enterprises (SOE) in Kosovo over Kosovo Trust Agency}

\section{Models}

Temporary civilian United Nations Mission in Kosovo (UNMIK), Department over for Trade and Industry as part IV of the stairs, at the beginning started to investigate the privatization model. After four years of delay, efforts have been unsuccessful. The previous models that were applied in the states of former Yugoslavia were unacceptable; the models that had been used in Eastern Europe were also incompatible. The voucher model, for example, could not be implemented for many reasons and above all due to lack of basic legal status of Kosovo. For these reasons, UNMIK had to come up with a special process of privatization that had not been used anywhere else before. The novelty of this process was that it had in mind the following:

1. Sell the main assets of the company through tender, while the remaining assets would be sold separately through liquidation.

2. Land assets were subleased for 99 years, because a lot of the cadastral information had been lost during the war (they had been taken elsewhere, mainly in Serbia).

3. Led by the experience that others have crossed the country in the process transformation and privatization of property, UNMIK through the Kosovo Trust Agency, privatization of SOEs joined by her model was included in the three forms of privatization:

4. Regular Spin-off

5. Special spin-off

6. Liquidation

Regular spin-off ("amputation") - Rules of Tender for the spin-off privatization (the circular closure, which involves only the sale of assets of enterprises, namely, within the existing company formed a new company that includes only the assets of the company, and shall remain in old company, which will later apply the process of liquidation, the funds from the sale go into a special fund under the control of the KPA and will be used to settle liabilities to creditors, owners and workers). The model of an old company can develop more new enterprises, while funds raised during the sale of share in a way that 
$20 \%$ goes to workers while $80 \%$ goes to fund the trust that will serve to cover obligations made during the operation of the old company.

A part from a small number of obligations (property taxes for the past 12 months, payment of public services for the last 3 months), the new owner of the company being acquitted of all other obligations that the company had previously.

Special spin-off - apart from the rules that are worth for a regular spin-off, special spin-off added to the model are still some limitations for the new owner of the company. In fact this model, the owner must complete and obligations that were in the process of tendering and to have:

1. highest price offered in the tender,

2. investments that will be the time period,

3. retain workers previously employed and increase the number of workers over a given period of time.

Although it was sold this model, we cannot boast of having succeeded. Enterprises privatized in this model are mostly continued the previous activity.

Liquidation - Although proposed as a model for privatization of parts of companies or enterprises as a whole, during the existence of the KTA has partially implemented and as far as the liquidation process, it is not implemented. As a model could be implemented in a small number of firms that were small-scale or those that have already been plenty of earlier stopped working and who have been in bankruptcy proceedings.

\section{Few final findings and notices about privatization in Republic of Kosovo}

Few findings and notices about privatization process of Socially Owned Enterprise in Republic of Kosovo are as follows;

a) Some evaluations about flow and results of privatization program;

b) Opinion and some attitudes of the citizens about the process.

c) Few valuations and notices about results of privatization in Republic of Kosovo

Results of privatization reached up to now are under those expected in public. This is specially related to:

(1) delaying of the process;

(2) slowness of tender sale;

(3) braking contract in previously privatized companies.

The question that is set: whether gap between real results and expected results of privatization is consequence of low realization or exceeded high expectations from privatization? According to my opinion, the size of gap is under influence of both determinants.

Beside all problems (political instability, war, bombing) larger determination of Government for privatization at the practical level (specially state bodies) would, even in that conditions, gave better results. From the other side, it was too much pointed that privatization will solve many problems. In the mind of ordinary man, privatization is usually understood as form of renewal, i.e., if someone who buys the company brings the money, salaries and debts are paid and all remains the same: management, number of employees, production program ... That understanding is result of many renewal programs that were conducted in previous system in Serbia and Yugoslavia.

A non-doubtful result of the process is increased participation of private sector in GDP and growth of employment in that sector. In the same way, privatization has encouraged creation of new enterprises and development of those enterprises. Privatization and generally development of private business in Republic of Kosovo had influenced the understanding of major part of population (especially young) that it should expect only from the state to solve the problems, but that each individual should seek solution for itself! 
As result of change of property structure the change of attitude toward foreigners and foreign investors can be stated. The fear of foreign investors is smaller and smaller, however it still exists in some state and political groups and is motivated by their fear that foreigners could put in danger their interest sphere, then they really think that presence of foreigners is bad by itself. Existence, respectively acceptance of Privatization Plan and providing that everything can be private (there is no priory enterprises that cannot be privatized), and that foreigners have national treatment, as well as determination that property and contracts can be protected at first step international courts, are also important result whose consequences can be important for next phase of privatization.

Established basic institutional framework of privatization, as well as expert basis is without doubt important result that will influence further reforms in Republic of Kosovo.

There are few indicators of economy effects that are showing at insufficient results in this process:

- $\quad$ Even there are changes in the property structure; still participation of state sector in total economy is large.

- Participation of foreign investments in Republic of Kosovo up to now is very low, much lower than in Croatia and Slovenia, and not to speak about Hungary, Poland, and Check Republic.

- $\quad$ Privatization incomes are modest.

- Recent level of privatization didn't have influence on the development of efficient capital market.

- Corporate governance is much more showing as problem even in private companies.

- Insider privatization model of privatization in Republic of Kosovo hasn't up to now gave results in new investments, restructuring enterprises and improving corporate finance.

- Problem of restitution remains open and unsolved, what creates unpleasant climate for complete privatization process.

- The number of companies at bankruptcy or entering zone of bankruptcy is increasingly larger.

\section{Some social - psychological attitudes of citizens as indicators of their readiness for privatization}

We are stating few results of research that was conducted for purposes of this thesis. The research about social and psychological attitudes of citizens was done at sample of 611 participants, where 200 participants were from Republic of Kosovo.

Interest for privatization. More than $60 \%$ of citizens in Republic of Kosovo are highly interested for privatization. Only $10 \%$ of people are not interested for privatization, and manly these participants are belonging to the age group below 20 years.

Information and sources of information. Each third participant from Republic of Kosovo estimates that hadn't information about privatization Still, answer like this is indicating uncertainty of citizens concerning privatization, and not only weak information.

How much citizen knows about privatization? The certain number of questions has been set in order to test knowledge of citizens about privatization. The percentage of correct answers about privatization was $34,3 \%$.

Attitude toward privatization. This dimension has been measured with range of attitudes with score from 5 to 30 . Valuation was done so that higher score represents more positive attitude toward private property positive attitude is higher in Republic of Kosovo.

Relation between individualism and collectivism. It was measured with the same range as attitude toward private property. Tendency toward individualism is higher in Pristina $(25.1 \%)$ then in other cities, where is below $20 \%$. 
Almost $63 \%$ participants have positive attitude toward privatization with relatively small participation of those with negative attitude.

Expected effects of privatization. About $65,8 \%$ participants expect increase of unemployment because of privatization; to solve problems of old foreign saving thinks $42,1 \%$; fear that by fraud in privatization small number of favored people will become rich thinks $78 \%$, that privatization will results with membership in the international community $51,4 \%$; all that is worth will buy foreigners $68,3 \%$; employees will finally be paid for their work thinks $23,6 \%$; honest people won't get anything from privatization $55,4 \%$.

Generally, nothing better predicts the readiness of people for changes that is privatization bringing than readiness to change property relations. From the other side, from all social demography indicators, education and working place are in certain measure connected with acceptance of privatization. What is level of education higher, the readiness of people to accept changes that is privatization bringing higher, as well as level of information they have is higher.

Concerning working place, for privatization is most interested, best informed, have largest knowledge and most positive attitude those who have already entered privatization process.

This research has shown that information needs, respectively needs for higher education of public in area of privatization in Republic of Kosovo are large need.

All previous comments and findings point to fact that transition to the new, more economically, institutionally and legally based model of privatization, required by itself a large amount of work at creation the institutional assumptions and introduction of stronger order in the privatization process compared to earlier period. Besides that, in the same period different oversights and deficiencies from former period have come up to the surface.

Individuals that took part in the privatization, in majority of privatization in first years, are starting to intensively include in the critic of privatization process, mainly directly and who had because of "conceptual reasons" of new organization of privatization been excluded, as well as part of coalition at power that has "broken". To many, critic of privatization has served for covering some personal activities in the privatization process.

Some decision of the Privatization council provoked gall discussions that were motivated by introduction of larger order and procedures in area of privatization.

However, Privatization Council and all others participants in privatization, step by step built and raise confidence in privatization process, and gradually changed opinion of the public about privatization. So, two periods can be distinguished in the privatization in Republic of Kosovo: prior to 1999 and after 2005.

Privatization in Republic of Kosovo was conducted as a project, not as a job of certain ministry. Privatization project was and still is managed by PAK. Technical work for privatization was done by Agency.

The example of Republic of Kosovo is showing that managing economy and the method of decision-making is important international resource of efficiency and transparency of the process. Through, it has shown also that this model is very vulnerable from aspect of political parties in coalition that depending on the problem, tried to impose domination of their interest. However, in the struggle of political parties to "make profit" from privatization by making distance from any contestable case in privatization and approach that concrete result with strict respect of the rules is the only argument concerning successful privatization: what was a saying of PAK.

We may conclude the analysis with the following observations:

First, privatization has substantial macro impacts in countries with low incomes, large population, considerable unemployment, wide income disparities, and regional differences in development. Limited market sizes often aggravate the problems.

Second, implicit in the analysis of the impacts-both micro and macro-is the problem of measurement. This is the more complex; the more difficult it is to identify the impacts definitely attributable to privatization.

Third, the processes of privatization warrant monitoring, in order to establish how effectively the objectives of privatization attached to individual cases or categories of cases are being realized, how transparent the processes of privatization 
happen to be in practice, and what basic changes in the structure of the national economy are being brought about by the processes of privatization.

Fourth, the impacts of privatization constitute such a wide range that they do not all produce a uniform result. The concept of trade-offs deserves attention. Certain direct and immediate results need to be considered alongside certain others which might be less direct and immediate, before the net benefit or cost to the economy is established. Of course, one has to decide on how far to go in identifying the results beyond the first-round effects.

Fifth, privatization calls for preparedness in the area of regulation aimed at exorcizing the unwelcome impacts.

Sixth, in many developing countries and centrally planned economies in transition the role of the state in steering economic development will not cease to be important-though it has to be different from what it has been - or else the impacts of privatization can be too anarchic to sustain distributional equity and social stability.

It would be desirable for analysts, policy makers and practitioners to focus attention on establishing the impacts of privatization, on monitoring privatization, on regulation post-privatization, and on redefining the precise role of the government in the development strategy specific to a country. These items should have high priority in work program relating to privatization.

In the Kosovo's macro-economic policy and programming great attention is given to privatization as a key element in the transition to a market economy system and including in European and World economic trends. Yet, there is need for further measures to improve the macro-economic situation and to remove the constraints which have been impinging on privatization actions. In doing so, greater attention should be given to the policy harmonization of the requirements of privatization, new private entrepreneurship (the creation of private firms) and restructuring of firms earmarked for long-term state ownership.

Although Kosovo's privatization process is not so quick in comparison with that in other countries, it is somewhat lagging behind the desired and potential speed. In order to speed up further privatization, beyond the removal of constraints discussed above, there is need for a flexible use of various privatization methods of both divestiture and non-divestiture types.

In Hungary's privatization process too much emphasis was put on the so-called 'active' privatization programs, the aim of which was, with the active participation of the state (PAK), the acceleration of privatization by attracting new circles of investors into the Kosovo's economy.

However, the speeding up of privatization in last few years could be attributed not to this program but rather to a new, investor initiated privatization method and to the so-called self-privatization method extending the range of participants.

The latter makes possible the transformation and sale of companies without direct involvement from the state, but with one of by the PAK through competition. Furthermore, greater attention should be given to methods like the breaking up of monopolies, leasing, management contracts and worker and management buy-outs, as well.

Foreign capital can also play an important role in speeding up the privatization process given the shortage of domestic capital. Its role is also crucial in the transfer of technical and managerial knowhow. From among the impacts of privatization the large labor redundancies resulting from the restructuring of firms deserve special attention and call for active employment and social policies.

There is need for intensive future activities in estimating likely impacts, both favorable and unfavorable, ex ante. Without such activities a 'culture' of privatization in the widest sense can hardly be built up.

\section{References and consulted literature}

[1] Aghion, P., Blanchard, O. and Burgess, R. (1994a), "The behaviour of state firms in EasternEurope, pre-privatisation", European Economic Review, Vol. 38, pp.

[2] Aghion, P., Blanchard, O. and Carlin, W. (1994b), "The economics of enterprise restructuring in Central and Eastern Europe", CEPR Discussion Paper No. 1058, CEPR, London 
[3] Aleksandar Štulhofer, povratak u budućnost?: proces privatizacije i hrvatska javnost 1996. - 1998, Objavljeno 1999. godine u zborniku Privatizacija i javnost /ur. D. Čengić i I. Rogićl. Zagreb: Institut društvenih znanosti I. Pilar

[4] Alexis, M. (1982), "The applied theory of regulation: political economy at the Interstate Commerce Commission", Public Choice, Vol. 39,

[5] Bothwell, J.L. (1980) 'Profitability, Risk, and the Separation of Ownership from Control'. Journal of Industrial Economics 28(3) (March): 303-11. Bowen, S. (1997) 'Bolivian Watchdog Proud of its Teeth'. Financial Times,27 July: 7.

[6] Boycko, M., A. Shleifer, and R.W. Vishny (1994) 'Voucher Privatization'. Journal of Financial Economics 35:

[7] Hoti, Avdullah, 2004: 'Human Capital and Unemployment in Transition:The Case of Kosova', RIINVEST, Prishtinë.

[8] Human Rights Centre of the University of Prishtinë, 2008: 'Economicand Social Rights', Prishtinë.

[9] Iraj Hashi: Privatisation Strategy for Kosovo: What can we learnfrom other transition countries?, Stanford University,. January 2001.

[10] Selman Selmanaj - Sistemet ekonomike bashkëkohore, Pristina 1996

[11] UNMIK Rregullations 1999/01

[12] UNMIK Rregullations. 2001/9,

[13] UNMIK Rregullations.2002/12 clan 17

[14] UNMIK Rregullations 2002/13

[15] UNMIK Rregullations 2005/18

[16] Law for Kosovo Trust Agency 